\title{
PENGARUH LATIHAN BALL FEELING TERHADAP KEMAMPUAN DRIBBLING SISWA SMP NEGERI 12 LUBUK LINGGAU
}

\author{
Fery Herwansyah, Wachid Sugiharto \\ Universitas PGRI Palembang ${ }^{1,2}$ \\ Fery.Herwansyah@gmail.com
}

\begin{abstract}
Abstrak
Penelitian ini bertujuan mengetahui adakah pengaruh latihan ballfeeling terhadap kemampuan dribbling pada siswa ekstrakurikuler SMP Negeri 12 Lubuklinggau. Tujuan penelitian ini untuk mengetahui ada tidak pengaruh latihan ball feeling terhadap kemampuan dribbling pada siswa ekstrakurikuler SMP Negeri 12 Lubuklinggau. Metode penelitian yang digunakan adalah metode penelitian Eksperimen semu. Populasi penelitian ini adalah siswa ekstrakurikuler sepak bola ekstrakurikuler SMP Negeri 12 Lubuklinggauyang berjumlah 18 orang.Teknik sampling menggunakan purposive sampling. Teknik analisis data dalam penelitian ini menggunakan ujit $t$. Hasil penelitian ini menunjukan bahwa ada pengaruh yang signifikan dari latihanlatihan ball felling terhadap keterampilan dribbling siswa ekstrakulikuler SMP Negeri 12 Lubuklinggau.Nilai pada $t_{\text {hitung }}>t_{\text {tabel }}$ dengan nilai 6,82>2,10. Dari hasil tersebut dapat dikatakan adanya pengaruh karena $t_{\text {hitung }}$ lebih besar daripada $t_{\text {tabel }}$ dengan taraf signifikansi hasil uji statistik $5 \%$.Sehingga dapat disimpulkan bahwa Ha diterima dan Ho ditolak.
\end{abstract}

Kata kunci : Metode latihan, Ball Felling, dribbling.

\section{THE EFFECT OF BALL FEELING EXERCISE TOWARD STUDENTS DRIBBLING PERFORMANCE ON THE STATE JUNIOR HIGH SCHOOL NUMBER 12 LUBUK LINGGAU}

\begin{abstract}
This study aims to determine whether there is an effect of ballfeeling training on dribbling ability in extracurricular students at SMP Negeri 12 Lubuklinggau. The purpose of this study was to determine whether there was an effect of ball feeling training on the dribbling ability of extracurricular students at SMP Negeri 12 Lubuklinggau. Research method used is quasi experimental. The population of this study were 18 students of extracurricular football extracurricular activities at SMP Negeri 12 Lubuklinggauyang. The sampling technique used purposive sampling. The data analysis technique in this study used the t test. The results of this study indicate that there is a significant effect of ballfelling training on the dribbling skills of extracurricular students at SMP Negeri 12 Lubuklinggau. The scores on $t_{\text {count }}>t_{\text {table }}$ with a value of 6.82> 2.10. From these results it can be said that there is an influence because t count is greater than $t$ table with a significance level of $5 \%$ statistical test results. So it can be concluded that Ha is accepted and Ho is rejected.
\end{abstract}

Keywords: Exercise method, Ball Felling, dribbling.

Correspondenceauthor: Fery Herwansyah, Wachid Sugiharto, Universitas PGRI Palembang, Indonesia. E-Mail: shugy.wahid@gmail.com (c) (i) (2)

Jurnal HalamanOlahraga Nusantara licensed under a Creative Commons Attribution-ShareAlike 4.0 International License. 


\section{PENDAHULUAN}

Pendidikan olahraga merupakan hal penting didalam kegiatan sekolah untuk mewujudkan manusia seutuhnya yang bugar dan berkarakter mulia.Nilai olahraga sangat membantu tujuan pendidikan yaitu memanusiakan manusia. Manusia yang ideal adalah manusia yang bugar jasmani dan rohaninya. Cabang olahraga yang dapat mendukung kebugaran dan pembentukan karakter elok termasuk olahraga sepakbola (Oktadinata, 2018).

Sepakbola adalah cabang olahraga yang digemari dan terkenal didunia juga sangat memasyarakat di negara Indonesia (Okilanda, Dlis, Humaid \& Putra., 2020). Kelebihan dari olahraga sepakbola ini adalah semua orang mampu melakukannya tidak memandang jenis kelamin,usia, jabatan, suku, agama dan lain sebagainnya, asalkan ada kemauan dan motivasi yang kuat semua orang bisa melakukan olahraga sepakbola dengan baik (Fajar, 2019). Permainan sepakbola dewasa ini banyak ditampilkan oleh atlet yang memiliki skill teknik yang baik . Skill teknik olahraga tidak dapat dicapai secara instan, harus melalui proses latihan yang membutuhkan waktu cukup lama (Daryono, 2019). Teknik permainan sepakbola banyak sekali bentuknya sehingga membutuhkan proses untuk melatih berbagai tekniknya. Gerak dasar permainan sepakbola (Luxbacher, 2011) Meliputi: (1) gerak atau teknik tanpa bola. Selama dalam sebuah permainan sepakbola, seorang pemain harus mampu berlari dengan langkah pendek maupun panjang kearena harus merubah kecepatan lari.Gerakan lainnya seperti berjalan, berjingkat, melompat, meloncat, berguling, berputar, berbelok, berkelit dan berhenti tiba-tiba. (2) gerak atau teknik dengan bola meliputi: (a) (ball feeling), (b) (passing), (c) (shooting), (d) (dribbling), (e) (receiveing and controlling the ball), (f)(heading), (g) (feinting), (h) (sliding tackle-shielding), (i) (throw-in), (j) (goal keeping).Untuk menjadi seorang pemain sepakbola yang baik, dimulai latihanpada usia 8-10 tahun dan usia puncak prestasi pada usia 18-20 tahun (Bompa, 1994: 34).

Usia spesialisasi pemain sepakbola usia 14-16 tahun. Dalam rentang waktu antara usia 10-18 tahunseorang pemain dilatihkan dengan bentuk keterampilan dasar sepakbola sehingga memiliki skill sepakbola yang baik. Pemain yang 
memiliki skill dasar sepakbola yang baik tidak akan menemui banyak kesulitan saat dalam permainan, misalnya dalam menggiring bola (dribbling) (Okilanda, 2017). Salah satu teknik dengan bola yang harus dikuasai oleh pemain adalah teknik menggiring bola (dribbling). Pelatih berperan penting dalam memberikan pelbagai macam bentuk latihan yang dapat meningkatkan dribbling pemain. Pelatih dituntut untuk dapat dinamis dalam membuat program dan sesi latihan.

Menurut Djoko pekik Irianto (2002: 11-12) latihan adalah proses pelatihan dilaksanankan secara teratur, terencana, menggunakan pola dan sistem tertentu, metodis serta berulang seperti gerakan yang semula sukar dilakukan, kurang kordinatif menjadi semakin mudah, otomatis dan reflektif sehingga gerak menjadi lebih efisien dan itu harus dikerjakan berkali-kali. Berdasarkan dari beberapa ahli di atas, maka dapat disimpulkan bahwa pengertian latihan adalah aktifitas yang meningkatkan ketrampilan (kemahiran) atlet dengan tujuan tertentu yang dilakukan secara terprogram, sistematis dan logis berbasis sport science. Manfaat latihan sangat berpengaruh pada pengembangan atlet baik secara mental, fisik, tehnik maupun taktik.

Seorang pemain yang memiliki kemampuan menggiring bola yang baik, akan dengan mudah mengembangkan permainan pada saat bertanding (Danny Mielke, 2007: 1). Pengertian dribbling adalah membawa bola dengan menendang terputus-putus atau pelan-pelan dengan kaki yang digunakan untuk menggiring bola selalu berdekatan serta bersentuhan. Menggiring bola dalam permainan sepakbola bertujuan untuk melewati lawan, untuk mendekati daerah pertahanan lawan, untuk membebaskan diri dari kawalan lawan, untuk mencetak gol dan melewati garis bebas. Bagian kaki saat menggiring bola hampir sama dengan saat melakukan passing bola bawah, yaitu sisi kaki bagian dalam, punggung kaki bagian dalam, punggung kaki bagian luar. Dalam menggiring bola, seorang pemain dapat menggunakan beberapa bagian kaki seperti punggung kaki, punggung kaki bagian luar, punggung kaki bagian dalam, dan menggunakan kaki bagian dalam.Penggunaan kaki tentu saja disesuaikan dengan keadaan atau kondisi dilapangan dan posisi lawan (Luxbacher, 2012). 
Keterampilan dasar sepakbola harus dikuasai oleh siswa ekstrakurikuler, dan melalui pengamatan lapangan masih terlihat keterampilan teknik dasar siswa ekstrakurikuler SMP Negeri 12 Lubuklinggau masih banyak yang kurang maksimal, contohnya sajauntuk dribbling perkenaan kaki terhadap bola masih salah, penguasaan bola saat dribbling masih jauh dari jangkauan atau kaki, pandangan saat dribbling masih sering tertuju pada bola, kecepatan dribbling belum optimal. Menurut pengamatan peneliti dan informasi dari para atlet hal tersebut dapat terjadi karena metode melatih yang masih monoton, sehingga mengakibatkan siswa jenuh dan dapat menurunkan motivasi siswa untuk berlatih.Hal ini yang mungkin menyebabkan keterampilan teknik dribbling siswa ekstrakurikuler SMP Negeri 12 Lubuklinggau masih kurang bagus.Oleh karena itu peneliti berkeinginan meneliti terkait pengaruh latihan ball felling terhadap keterampilan dribbling siswa ekstrakurikuler SMP Negeri 12 Lubuklinggau.

\section{METODE}

Metode penelitian ini adalah penelitian eksperimen semu karena tidak ada kontrol. Menurut Arikunto (2010) penelitian eksperimen merupakan penelitian yang dimaksudkan untuk mengetahui adanya akibat atau tidak terhadap subjek yang dikenai perlakuan.Perencanaan program latihan ball feeling sebagai perlakuan disusun sesuai kaidah latihan untuk meningkatkan pengaruh kemampuan dribbling. Sebelum perlakuan dimulai terlebih dulu dilakukan tes awal/pretest, kemudian dilakukan tes akhir/ posttest setelah perlakuan.Jika hasil tes akhir ada peningkatan secara signifikan dari tes awal maka terdapat pengaruh. Desain yang digunakan adalah"one groups pre-test-post-test design"(Winarno, 2007). Adapun desain penelitian sebagai berikut:

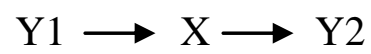

Keterangan:

Y1: Pretest

$\mathrm{X}$ : Perlakuan

Y2: Postest 
Populasi adalah keseluruhan subjek penelitian (Arikunto, 2010). Populasi adalah wilayah generalisasi yang terdiri atas objek atau subjek yang mempunyai kuantitas dan karakteristik tertentu yang ditetapkan oleh peneliti untuk dipelajari dan kemudian disimpulkan (Sugiyono, 2008). Populasi dalam penelitian ini 31 orang adalah siswa ekstrakurikuler SMP Negeri 12 Lubuklinggau". Menurut Sugiyono (2008) sampel adalah sebagian dari jumlah dan karakteristik yang dimiliki oleh populasi. Teknik sampling dalam penelitian ini menggunakanpurposive sampling. Purposive sampling adalah teknik penentuan sampel dengan pertimbangan tertentu (Sugiyono, 2008). Kriteria dalam penentuan sampel ini meliputi: (1) daftar hadir minimal 75\% (keaktifan mengikuti latihan), (2) berusia 13-15 Tahun, (6) lama latihan minimal 1 bulan. Berdasarkan kriteria tersebut yang memenuhi berjumlah 18 siswa.

Instrumen penelitian ini menggunakan tes kemampuan menggiring bola (dribbling) (Widiastuti \& Pd, 2011) dengan hasil uji kesahihan sangat signifikan 0,763 dan ujikeandalan $r=0,637$. Tujuan mengukur tingkat kecakapan menggiring bola. Teknik analisis data menggunakanuji-t setelah dilakukan uji normalitas dan uji homogenitas.Untuk menguji pengaruh latihan ball feeling terhadap kemampuan dribbling digunakan uji T dengan bantuan SPSS versi 21.00, yaitu dengan membandingkan mean antara pretest dan post-test. Apabila nilai t hitung lebih kecil dari t tabel, maka Ha ditolak, jika t hitung lebih besar dibanding t tabel maka Ha diterima.

\section{HASIL DAN PEMBAHASAN}

Pengambilan data dilakukan yaitu pada awal pertemuan atau pertemuanpertama untuk mendapatkan kemampuan awal (pretest)dan pada pertemuan terakhir untuk memperoleh hasilbelajar setelah diberikan treatmen (posttest). Analisis datayang digunakan adalah uji t dependent sample dengantaraf signifikan 0,05 dan selanjutnya akan dihitungpeningkatannya. Data hasil penelitian ini terdiri nilai rata-rata, simpangan baku, varian,distribusi frekuensi, dan histogram yang disajikan seperti berikut ini: 
Tabel 1. Deskripsi Data

\begin{tabular}{cccc}
\hline Deskripsi & PRE TEST & POST TEST & Selisih \\
\hline Mean & 26,46 & 20,97 & 5,50 \\
SD & 3,12 & 1,39 & 1,73 \\
Varian & 9,75 & 1,94 & 7,81 \\
\hline
\end{tabular}

Tabel 1 dapat diketahui bahwa deskripsi data hasil dribbling bola sebelum pembelajaran (pree test) yaitu nilai rata-rata sebesar 26,46; nilai standar deviasi sebesar 3,12; dan nilai varian sebesar 9,75. Setelah dilakukan treatmen makan diperoleh hasil dribbling bola setelah pembelajaran (post test) yaitu nilai rata-rata sebesar 20,97; nilai standar deviasi sebesar 1,39; dan nilai varian sebesar 1,94. Secara lebih jelas penyebaran distribusi frekuensi data hasil keterampilan dribbling bola siswa Ekstrakulikuler SMP N 12 Lubuklinggau dapat dilihat pada histogram berikut:

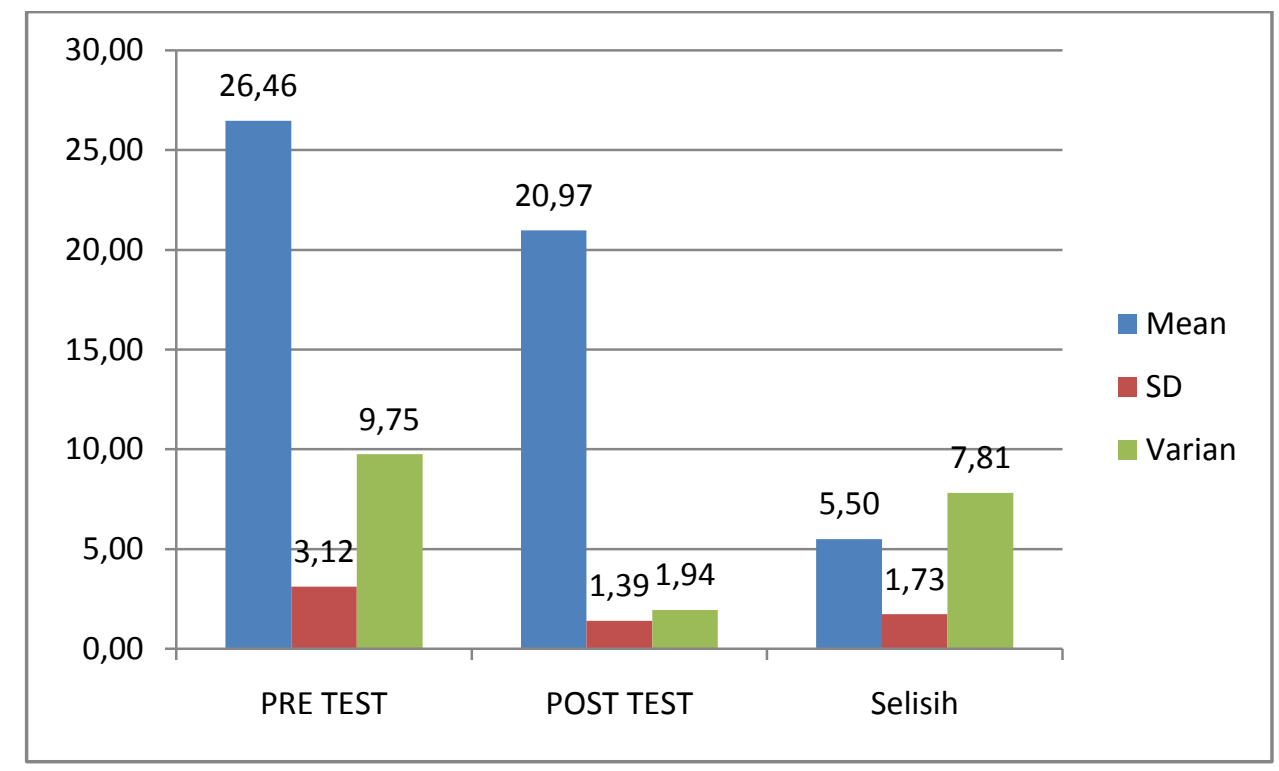

Gambar 1 Histogram data Preetest dan Post Test

Setelah pengujian normalitas data dan homogenitas data, sehingga data tersebut dinyatakan berdistribusi normal dan varians dalam penelitian bersifat homogen, maka tahap selanjutnya yang dilakukan adalah pengujian hipotesis penelitian dengan menggunakan statistik parametrik, yaitu rumus Uji-t : 
Tabel 2 Uji Hipotesis Menggunakan Uji-t

\begin{tabular}{ccccc}
\hline $\begin{array}{c}\text { Perbedaan } \\
\text { Nilai }\end{array}$ & $\mathbf{N}$ & $\mathbf{t}_{\text {hitung }}$ & $\mathbf{t}_{\text {tabel }}$ & Keterangan \\
\hline $\begin{array}{c}\text { Pre Test } \\
\text { Post Test }\end{array}$ & 18 & 6,82 & 2,10 & Signifikan \\
\hline
\end{tabular}

Berdasarkan tabel di atas dapat dijelaskan bahwanilai pada $t_{\text {tabel }}>$ $\mathrm{t}_{\text {alpha }}$ dengan nilai $` 6,82>2,10$. Dari hasil tersebut dapat dikatakan adanya pengaruh,

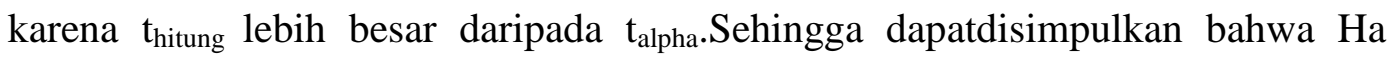
diterima dan Ho ditolak atauterdapat pengaruh latihan ball felling terhadap keterampilan dribbling siswa ekstrakulikuler SMP N 12 Lubuklinggau.

\section{KESIMPULAN}

Berdasarkan penelitian yang telah dilakukan maka dapat ditarik sebuah kesimpulan sebagai berikut: "Terdapatpengaruh latihan ballfeeling terhadap kemampuan dribbling pada siswa ekstrakurikuler SMP Negeri 12 Lubuklinggau. Penelitian ini berimplikasi kepada:Pelatih mempunyai berperan strategis dalam monitor perkembanganatlet pada saat berlatih, dalam upaya mengembangkandribbling dengan terlebih dahulu melakukan latihanball feeling. Latihan ball feeling dapat membantu peningkatan keterampilan dribbling atlet. Bagi pelatih, diharapkan memberikan latihan ball feeling agar dribbling atlet semakin baik. ball feeling dengan menggunakan bola di rumah.

\section{DAFTAR PUSTAKA}

Arikunto, S. (2010). Prosedur Penelitian Suatu Pendekatan Praktik. 2010. Jakarta: Rineka Cipta. 
Daryono, D. (2019). Survei Tingkat Kesegaran Jasmani Pada Peserta Ekstrakulikuler Sepakbola Di Sma Negeri 2 OKU. Halaman Olahraga Nusantara (Jurnal Ilmu Keolahragaan), 2(1), 21-28.

Fajar, M. (2019). Pengaruh Metode Latihan Terhadap Daya Tahan Fisik Siswa Ekstrakurikuler Sepak Bola Sma N 2 Tanjung Raja. Halaman Olahraga Nusantara (Jurnal Ilmu Keolahragaan), 2(2), 114-121.

Luxbacher, J. A. (2011). Sepak Bola edisi kedua. Jakarta: PT Rajagrafindo Persada.

Luxbacher, J. A. (2012). Sepak Bola: Langkah-langkah Menuju Sukses. Jakarta, Rajawali Pers.

Okilanda, A. (2017). Analisis Pembelajaran Gerak Keterampilan Teknik Dribbling Ssb Imam Bonjol Padang. Wahana Didaktika: Jurnal Ilmu Kependidikan, 15(3).

Okilanda, A., Dlis, F., Humaid, H., \& Putra, D. D. (2020). Perbedaan Pengaruh Metode Latihan Dan Motivasi Berlatih Terhadap Teknik Dasar Sepakbola Sekolah Sepakbola Beji Timur U-13. Jurnal Educatio FKIP UNMA, 6(1), 80-89.

Oktadinata, A. (2018). Pengaruh Metode Sirkuit Terhadap Kemampuan Teknik Dasar Sepakbola Pada Kegiatan Ekstrakurikuler Siswa Sma Negeri 5 Kabupaten Tebo. Halaman Olahraga Nusantara (Jurnal Ilmu Keolahragaan), 1(1).

Sugiyono. (2008). Metode penelitian pendidikan:(pendekatan kuantitatif, kualitatif dan $R \& D)$. Alfabeta.

Widiastuti, W., \& Pd, M. (2011). Tes dan pengukuran olahraga. Jakarta: PT. Bumi Timur Jaya.

Winarno, M. E. (2007). Research Methodology in Physical Education. Malang: Faculty of Education, Malang State University. 